\section{Kronisk pankreatitt - mer enn alkohol}

Kronisk og residiverende pankreatitt er ikke bare et resultat av for høyt alkoholinntak: Av 1000 pasienter med kronisk eller residiverende pankreatitt som var med i en amerikansk multisenterstudie, hadde én av fire vært avholdende hele livet (Arch Intern Med 2009; 169: 1035-45).

Svært stort alkoholkonsum, dvs. gjennomsnittlig over fem enheter per dag, var signifikant assosiert med pankreatitt (OR 3,1). Men bare $40 \%$ av mennene og $10 \%$ av kvinnene var i denne kategorien. Også røyking utgjorde en betydelig risikofaktor for pankreatitt, uavhengig av alkoholkonsum, men kunne igjen bare delvis forklare sykdommen.

\section{Ugunstig kombinasjon}

Komplekse sykdommer skyldes ofte et samspill mellom genetisk disposisjon og ugunstige miljøpåvirkninger. Nye data fra ungdommer i tvillingregisteret i Minnesota belyser hvordan gener og miljøfaktorer påvirker utviklingen av eksternaliserende psykiske lidelser, slik som antisosial atferd og alkoholmisbruk (Arch Gen Psychiatry 2009; 66: 640-8).

Resultatene viste at desto mer ugunstig miljøet var, jo sterkere kom den genetiske sårbarheten til uttrykk. Ugunstige miljøfaktorer inkluderte bl.a. lav utdanning, dårlig kontakt med venner og høyt konfliktnivå hos foreldrene.

\section{Molekylær mekanisme bak metastasering til hjernen}

Brystkreft kan spre seg til hjernen flere år etter primærbehandlingen. Dette indikerer at kreftcellene gjennomgår forandringer før de kan invadere hjernen. Det er nå nye forskningsdata om hvilke molekylære endringer som er karakteristiske for denne evnen (Nature 2009; 459: 1005-9).

Analyser av genuttrykk identifiserte genene cyklooksygenase 2 (COX2), EGFRliganden HBEGF samt $\alpha 2$, 6 -sialyltransferase (ST6GALNAC5) som viktige for cellenes evne til å krysse blod-hjerne-barrieren. De fant også at ST6GALNAC5-proteinet spesifikt påvirket hjerneinfiltrasjon, og ikke var involvert i metastasering til andre organer. Cellestudier viste at dette proteinet $ø$ kte kreftcellenes adhesjon til endotelcellene i hjernen, og at celler uten dette proteinet hadde redusert evne til å krysse blod-hjerne-barrieren.

\title{
Utvikling av kronisk lymfatisk leukemi
}

\author{
Analyser av lagrede blodprøver \\ fra en stor befolkningsundersøkelse \\ bidrar til å forstå utviklingen av \\ kronisk lymfatisk leukemi.
}

Kronisk lymfatisk leukemi er den vanligste formen for leukemi hos voksne i den vestlige verden, og forekomsten er spesielt høy i Skandinavia. Sykdommen kjennetegnes av en opphopning av monoklonale B-celler i beinmarg og lymfoide organer. Slike celler finnes imidlertid også hos friske omkring $5 \%$ av personer over 60 år har monoklonal B-cellelymfocytose, som er en parallell til den mer kjente tilstanden monoklonal gammopati med usikker klinisk betydning, som kan være forstadium til myelomatose. Risikoen for å utvikle kronisk lymfatisk leukemi for en person med monoklonal B-cellelymfocytose er omkring $1 \%$ per år - omtrent den samme som for at monoklonal gammopati utvikler seg til myelomatose.

En studie fra National Cancer Institute i USA viser at kronisk lymfatisk leukemi sannsynligvis alltid utvikler seg via monoklonal B-cellelymfocytose: Blant om lag 77000 deltakere i en populasjonsbasert nasjonal screeningundersøkelse fikk 45 personer senere diagnosen kronisk lymfatisk leukemi (1). Blodprøver tatt 3-6 år tidligere ble undersøkt med væskestrømscytometri og/eller PCR-metodikk for monoklonale B-celler. Hos alle unntatt én ble det påvist monoklonal B-cellelymfocytose. Det var ikke mulig å gjøre genetiske undersøkelser av cellene på begge tidspunkter, men analyser av de lette kjedene viste at klonene av B-celler sannsynligvis var de samme.

- Funnene har først og fremst betydning for å forstå sykdomsutviklingen bedre, sier professor Geir Tjønnfjord ved Medisinsk avdeling, Rikshospitalet. Vi kjenner ikke tiltak som kan redusere risikoen for transformasjon fra monoklonal B-cellelymfocytose til kronisk lymfatisk leukemi. Det er derfor ingen grunn til å iverksette systematiske undersøkelser for å avdekke monoklonal B-cellelymfocytose utenfor kliniske studier.

\section{Ragnhild Ørstavik \\ ragnhild.orstavik@fhi.no \\ Tidsskriftet}

\section{Litteratur}

1. Landgren O, Albitar M, Ma W et al. B-cell clones as early markers for chronic lymphocytic leukemia. N Engl J Med 2009; 360: 659-67.

\section{Screening for prostatakreft - igjen}

\section{Resultatene av to nye studier gir ingen sikre svar om nytten av PSA- \\ baserte screeningunders $\emptyset$ kelser \\ for prostatakreft.}

Bør man ha et screeningprogram for prostatakreft? Debatten har pågått i over ti år. Nå er det publisert to nye, store studier, der resultatene kanskje kan bidra til enighet eller kanskje ikke.

I den første, europeiske studien, ble 180000 menn inkludert. Screening reduserte den relative mortaliteten av prostatakreft med $20 \%$ (1). Mennene var 50-74 år gamle ved studiens begynnelse. De som inngikk i screeningprogrammet, fikk målt prostataspesifikt antigen (PSA) hvert fjerde år, og den totale oppfølgingsperioden var på ni år.

I den andre studien, som var fra USA, inngikk nesten 80000 menn (2). PSA-nivået ble målt årlig i seks år. Etter sju år var det flere dødsfall i screeninggruppen, men forskjellen mellom gruppene var ikke statistisk signifikant. I begge studiene var det også mange menn i kontrollgruppene som fikk målt PSA-mengden i serum, eller gjennomgikk rektal palpasjon av prostata. Prostatabiopsi ble tatt ved PSA-verdi større enn $3 \mathrm{ng} / \mathrm{ml}$.
- Den amerikanske studien viser ingen gevinst av screening, og den europeiske ingen reduksjon i total dødelighet, sier professor Truls Erik Bjerklund Johansen ved Urologisk avdeling, Århus universitetssykehus. - En manns risiko for å dø av prostatakreft er ca. $3 \%$. Når man snakker om $20 \%$ relativ mortalitetsreduksjon, er det viktig å huske at resultatene også viser at 48 pasienter måtte behandles for å unngå ett dødsfall i løpet av ti år. Overbehandlingen er sannsynligvis større i dag selv utenfor screeningprogrammer, fordi det tas flere prostatabiopsier på lavere PSA-verdier etter såkalt villscreening. Den europeiske urologforeningen erkjenner at screening for prostatakreft fører til en betydelig overbehandling og anbefaler sine medlemmer å være kritiske til bruk av invasiv behandling, sier Johansen.

\section{Ragnhild Ørstavik}

ragnhild.orstavik@fhi.no

Tidsskriftet

\section{Litteratur}

1. Schröder FH, Hugosson J, Roobol MJ et al. Screening and prostate-cancer mortality in a randomized European study. N Engl J Med 2009; 360 $1320-8$.

2. Andriole GL, Crawford ED, Grubb RL 3rd et al. Mor tality results from a randomized prostate-cancer screening trial. N Engl J Med 2009; 360: 1310-9. 